\title{
MODELING A RIVER-LAKE INTERACTION SYSTEM IN THE TONLE SAP LAKE AREA
}

\author{
ZHU, X. ${ }^{1,2}-\mathrm{WU}, \mathrm{S}^{3 *}-$ ISHIDAIRA, $\mathrm{H}^{4}$ \\ ${ }^{I}$ Water Resources Department of Jiangsu Province, Nanjing, Jiangsu 210024, China \\ ${ }^{2}$ College of Water Conservancy and Hydropower Engineering, Hohai University, Nanjing, \\ Jiangsu 210098, China \\ ${ }^{3}$ Jiangsu Hydraulic Research Institute, Nanjing, Jiangsu 210017, China \\ ${ }^{4}$ Department of Civil and Environmental Engineering, University of Yamanashi, Kofu, \\ Yamanashi 400-8511, Japan \\ *Corresponding author \\ e-mail:xk6sht@163.com
}

(Received $4^{\text {th }}$ Dec 2019; accepted $9^{\text {th }}$ Mar 2020)

\begin{abstract}
Mekong River-Tonle Sap Lake is a typical river-lake interaction system in a monsoon area. The Tonle Sap Lake (TSL) is the largest freshwater lake in Southeast Asia, and is an important component in lower Mekong River (MR) Basin. Water resource managers are highly concerned about the potential impact of climate change on the MR-TSL hydrological system in the future. Thus, it is necessary to develop a numerical model which can simulate MR-TSL interaction system for the assessment of potential impact of natural climatic variations on hydrological cycle in this area. The main objective of this study was to model a river-lake interaction system for water resource assessment in TSL area. The distinctive feature of this study is to develop an integrated River Lake Water Exchange (RLWE) model and couple it to a grid-based distributed hydrological model (YHyM) for MR-TSL system. Using the coupled model, discharge contribution to TSL from tributaries, lake water volume, water exchange between the MR and TSL, and consumptive water use in TSL area were simulated. The potential impact of climate change on TSL hydrological system was also assessed through the application of the coupled model. Several future scenarios were analyzed, and predictions of water budgets within the interaction system under different scenarios were made.
\end{abstract}

Keywords: water resource, hydrological model, GCM, water exchange system, potential impact

\section{Introduction}

River-lake interaction systems are significant in large river basins (Sutherland et al., 2018). The Mekong River (MR)-Tonle Sap Lake (TSL) is a typical example of such interaction in a monsoon area. The TSL plays a significant role, not only in the ecology of the lower Mekong River system, but also in the socio-economic life of Cambodia. Most of Cambodian population lives in the lower catchment of the MR basin, with more than 1 million people dependent on fishing for their livelihood (Keskinen, 2006; Kummu and Nikula, 2006; Campbell, 2016; Trisurat, 2018). Normal and reverse discharge occur in the Tonle Sap River. This unique hydrological phenomenon is a complicated river-lake interaction system. Due to rapid development in the upstream zone of TSL, hydrological changes in the TSL catchment have increased in the past decades. Climate changes and increased human activities in Mekong River Basin put the MR-TSL interaction system under a lot of stress, concerning water resources (Sverdrup, 2002; TERRA, 2007; Kummu et al., 2008; Ogston et al., 2017). However, 
not much is known about the interaction of hydrological processes, especially in the Tonle Sap Lake area, where insufficient historical gauge data is available (Fig. 1).

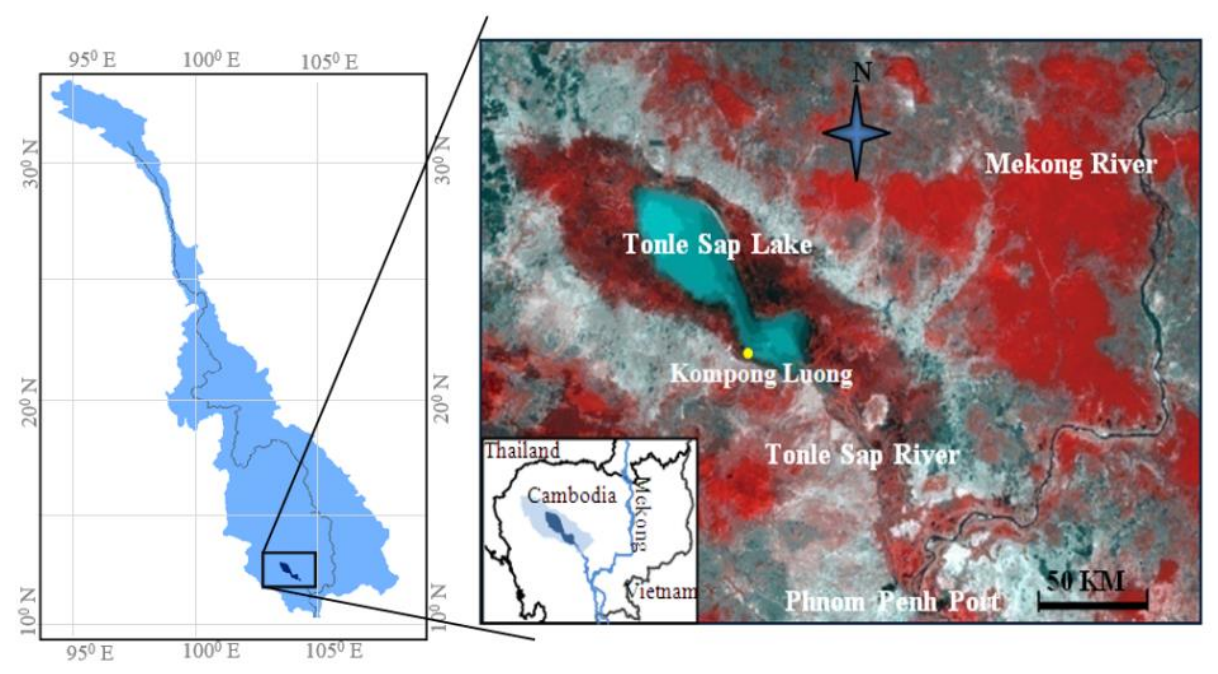

Figure 1. Map of location of Tonle Sap Lake area

It is important to investigate how future climate variations may affect the MR-TSL interaction system, and the consequences of these changes in the Mekong River Basin. This issue is highly important for the water resource managers. A comprehensive approach is needed to describe the complex interaction system and provide precise predictions under different future climate scenarios. The objective of this study is to understand the response of the hydrological system of TSL under future climate change, and to provide theoretical basis for water resource management.

\section{Study area}

The Mekong River Basin includes parts of China, Myanmar and Vietnam, and comprises nearly one third of Thailand and most of Cambodia and Lao PDR, with a total land area of $795000 \mathrm{~km}^{2}$. Tonle Sap Lake is an integral part of the Mekong River, located in the northwest part of Cambodia. The lake area has abundant resource such as forests, fisheries, wetlands and agricultural land. It is an important region for socioeconomic development of Cambodia. The TSL and its floodplains are located in the central part of Cambodia with the largest natural wetland habitats and the largest permanent freshwater body in Southeast Asia. This lake area is also a crucial source of food and livelihood in Cambodia. More than one million people who live in the area surrounding the Tonle Sap Lake and wetlands are highly dependent on agriculture and fishing (Sverdrup, 2002; Kummu et al., 2008; Chan et al., 2003).

The Tonle Sap Lake area has a tropical monsoon climate, with two distinct seasons i.e. rainy and dry seasons. The rainy season is from May to October. Normal and reverse discharge occur in the Tonle Sap River; this unique hydrological phenomenon constitutes a complicated river-lake interaction system. Mekong River-Tonle Sap Lake system includes Tonle Sap Lake, flood plain, Mekong River and Tonle Sap River. The Tonle Sap River connects the MR and TSL, with the confluence at Phnom Penh Port, as shown in Figure 1. Seasonal variations in Tonle Sap Lake floodplain are the determinants of the local ecosystem, fish production, livelihoods and inhabitants. In the 
rainy season, the increased rainfall rapidly accentuates the water level and discharge in Mekong River. In the Tonle Sap River, water flows from Mekong River into Tonle Sap Lake. At early May or late April, the water level in Tonle Sap Lake is about $1 \mathrm{~m}$, and the in-site lake area is only about $2.5 \times 10^{9} \mathrm{~m}^{2}$. As the incoming discharge from Tonle Sap River and tributaries is increased, the water level and inundation area of TSL rise gradually. In October, the water level of TSL peaks at over $10 \mathrm{~m}$, and the inundation area reaches up to about $1.5 \times 10^{10} \mathrm{~m}^{2}$. After October, the rainfall in the MR basin decreases, thereby reducing the water level and discharge in the Mekong River. Meanwhile, the water level of TSL also drops, but at a slower rate than that in MR because of the storage nature of the lake. The delay in reduction of water level in lake makes the TSL water level higher than that of MR. This water level difference changes the direction of discharge in Tonle Sap River from Tonle Sap Lake to Mekong River (hereafter, the flow from the lake to river is referred to as "reverse flow"). This discharge continues throughout the dry season up to late April or early May. Due to the normal and reverse discharges existing in the Tonle Sap River, huge water exchange occurs between the Mekong River and Tonle Sap Lake every year, and influence the seasonal variation and duration of flood inundation of the plain.

\section{Materials and methods}

\section{Yamanashi-distributed hydrological model}

The Yamanashi Distributed Hydrological Model (YHyM) is a grid-based distributed hydrological model developed by the University of Yamanashi, Japan (Takeuchi et al., 1999; Ishidaira et al., 2000; Ao et al., 2003a, b; Zhou et al., 2006a). It is a comprehensive system integrated with different modules such as meso-scale precipitation module, potential evaporation module, sediment transport module, run-off generation module, snow accumulation/melt module, water quality module, and water use/control (dam operations) module.

In this study, the core module BTOPMODEL was applied to generate hydrological boundary conditions for the TSL balanced system. The core module of YHyM, run-off generation module is based on extended TOPMODEL concepts (Ao et al., 1999, 2000, 2001, 2006; Takeuchi et al., 1999; Kiem et al., 2004a, b, 2005; Zhou et al., 2005, 2006a, b). The BTOPMODEL was used to divide the whole basin into a number of blocks/subbasins; each block/sub-basin may consist of several hillslopes, with water shared between hillslopes in each block, and no water exchange between blocks. The topographic index $\gamma$ was re-defined in Equations 1 and 2, for effectiveness in the gridbased applications, especially for large basin analysis:

$$
\begin{gathered}
q_{b i}=\left[a_{i} f\left(a_{i}\right) r_{k}\right] / a_{0 i} \\
\gamma_{i}=\ln \frac{a_{i} f\left(a_{i}\right) / a_{0 i}}{\tan \beta_{i}}
\end{gathered}
$$

where $f\left(a_{i}\right)\left(0 \leq f\left(a_{i}\right) \leq 1\right)$ is the effective contributing area ratio, i.e. the contribution rate of upstream net catchment area to discharge; $q_{b i}\left(\mathrm{~m} \mathrm{day}^{-1}\right)$ is the base flow of unit $i, r_{k}\left(\mathrm{~m} \mathrm{day}^{-1}\right)$ is the spatially homogeneous recharge rate over the block $k, a_{0 i}\left(\mathrm{~m}^{2}\right)$ is the area of the grid cell $I$, and $D_{i}\left(\mathrm{~m} \mathrm{day}^{-1}\right)$ is the ground water discharge ability: 


$$
q_{b i}=D_{i} \tan \beta_{i} \exp \left(-\frac{S D_{i}}{m}\right)
$$

where $q_{b i}$ is the outlet discharge in Equation 3, the subscript $i$ refers to the grid cell $i$, and a block-average value is used for $m$, the discharge decay factor.

The runoff routing used the Muskingum-Cunge method. The vertical column included vegetation zone, root zone, unsaturation zone and saturation zone. The runoff generation in each grid cell is shown in Figure 2.

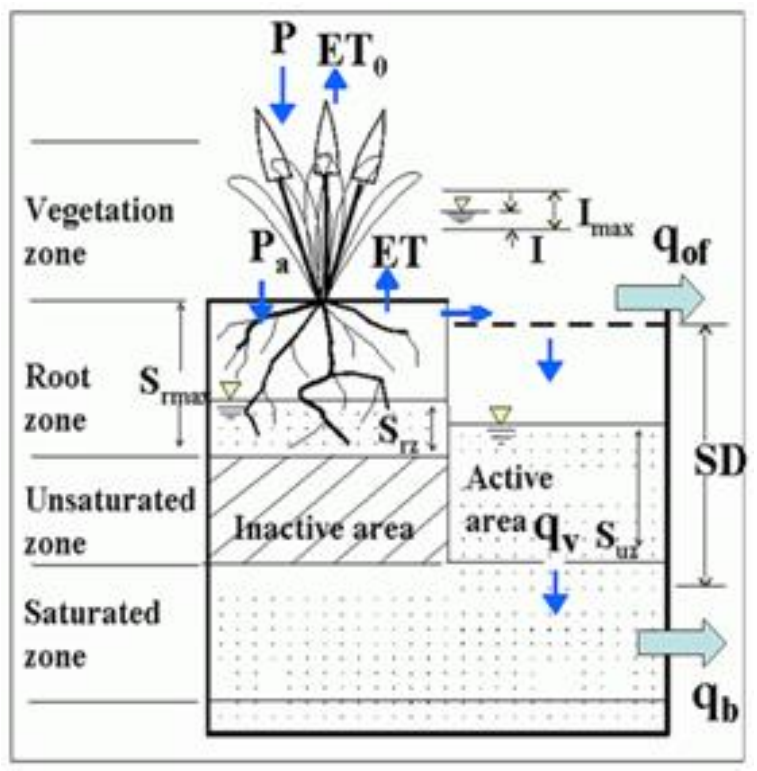

Figure 2. BTOPMC runoff generation structure

Three store layers are considered in this model: surface interception and depression store $\left(S_{1}\right)$, near surface infiltration store $\left(S_{2}\right)$ and saturated zone store $\left(S_{3}\right)$. The variable contributing area be outlined and the rainfall on this area will immediately become overland flow. Once the interception store is filled, the infiltration to $S_{2}$ can happen. Evaporation is allowed from this store at the estimated potential rate until it is empty. A constant leakage rate $i_{0}$ be applied for the infiltration to the $S_{3}$. The rate into $S_{2}$ is at the rainfall rate $i$ in Equation 4. However, if the rainfall rate is higher than the maximum infiltration rate $i_{\max }$ :

$$
i>i_{\max }=i_{0}+{ }^{b} / S_{2}
$$

The excess rainfall $\left(i-i_{\max }\right)$ becomes the infiltration excess overland flow. When the $\mathrm{S}_{2}$ reach its maximum storage, the saturation excess overland flow will happen. Evaporation are allowed from the infiltration store at a decreasing rate depending on the level of the store $\mathrm{S}_{2}$ in Equation 5:

$$
e_{a}=e_{r} S_{2} / S_{\epsilon}
$$

where $e_{r}$ is the potential evapotranspiration remaining once the interception store $S_{l}$ is depleted, and $e_{a}$ is the actual loss from the infiltration store. 


\section{RLWE model}

The river-lake interactive system in this research consisted of Tonle Sap Lake, its floodplain, Tonle Sap River, and Kampong Cham section to Phnom Penh Port section in main Mekong River. River Lake Water Exchange (RLWE) model was developed to simulate the hydrological process of the interaction system and to have an accurate understanding of the water balance system components.

The model was established based on water balance equation (Szesztay, 1974):

$$
V_{\text {in }}-V_{\text {out }}=\Delta V
$$

where $V_{i n}$ is the water volume going into Tonle Sap Lake, $V_{\text {out }}$ is the water volume going out from Tonle Sap Lake, and $\Delta V$ is the change in lake storage.

The water balance module was developed to simulate the hydrological cycle of TSL. Due to the huge seasonal area variation, the boundary of the TSL balance system was fixed in this research by the National Highway (NH) 5 and 6 as shown in Figure 3. Lake surface area fluctuates inside the NH boundary. The evapotranspiration in the balance system includes potential evaporation from water surface and actual evapotranspiration from flood plain not being inundated inside NH boundary.

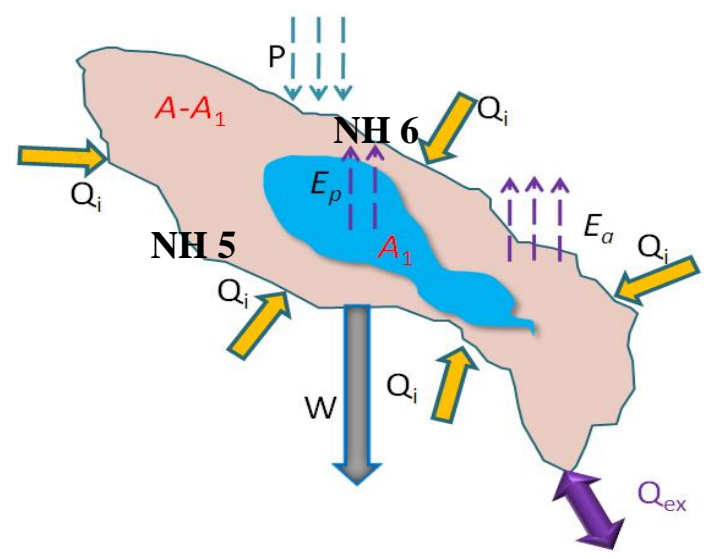

Figure 3. Balanced system of RLWE model

Thus, the water balance system for Tonle Sap Lake (Fig. 4) can be described in the following equation:

$$
\left.\left(P_{i}-E_{p i}\right) \times A_{1 i}+\left(P_{i}-E_{a i}\right) \times\left(A-A_{1 i}\right)+Q_{i j} \pm Q_{e x i}-W_{i}={ }^{\left(V_{j+1}\right.}-V_{j}\right) / \Delta t
$$

where $j$ is the time step (day) of computation, $P_{j}$ is the precipitation, $E_{p j}$ is the potential evaporation, $E_{a j}$ is the actual evaporation, $A$ is the area of the National Highway (NH) 5 and 6 boundary which works as the boundary of TSL water balance system, $A_{1 j}$ is the area of lake water surface, $Q_{i j}$ is the sum of the discharge from tributaries, $Q_{e x j}$ is the water exchange between the MR and TSL, $W_{j}$ is the amount of water consumption, $V_{j}$ is the lake water volume, and $\Delta t$ is the time interval of computation.

River Lake Water Exchange model consists of five sub-modules (Wu, et al., 2010): water level-water volume relationship sub-module, water level and discharge convert sub-module, water consumption sub-module, lake-river water exchange sub-module, 
and water balanced system. In this research, lake water storage income components included precipitation, water flow from tributaries, water flow from Tonle Sap River and part of the flood directly flowing into lake through floodplain. Outcome items consisted of potential evaporation from lake water surface, actually evaporation from floodplain, water flow from lake to Mekong River through Tonle Sap River, recharge to ground water, and domestic and irrigation water consumption.

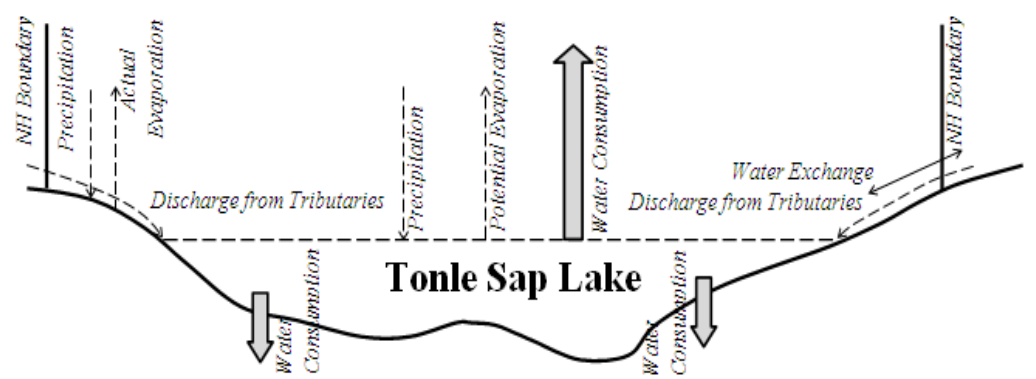

Figure 4. Water budgets in Tonle Sap Lake water balance system

\section{Coupled model by YHyM and RLWE}

\section{Introduction}

The hydrological system of TSL was simulated by coupling RLWE with YHyM. The structure of the coupling model system consisted of three layers (Fig. 5). The first layer (YHyM, a grid-based distributed hydrological model was applied to generate the boundary conditions including precipitation, evaporation, discharge from tributaries and discharge in certain cross sections in the main stream of the MR. These boundary conditions were regarded as the inputs for the second and third layers. The second layer was the RLWE model. Daily water consumption and water exchange between TSL and MR, and water level of TSL were calculated in this layer. The third layer was the water balance system of RLWE model. All the items in this system were derived from the first and the second layers. The daily water volume of TSL was calculated from the balance system, and used as the input in the next step.

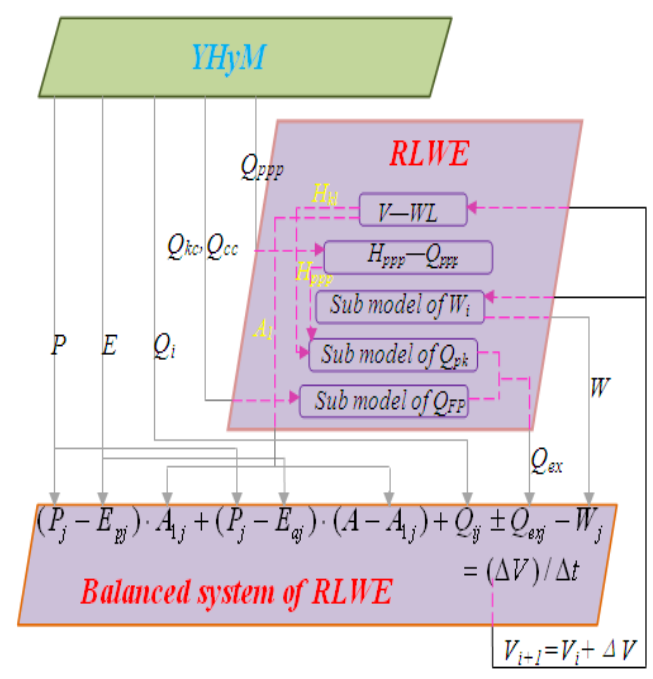

Figure 5. Structure generated by coupling RLWE with YHyM 


\section{Data set}

Observed daily water level data of Kompong Luong station from 1980 to 2002 were used to analyze the flood frequency of Mekong River. Daily observed water level data sets of Prek Kdam, Kompong Cham and Chroui Changvar stations from 1996 to 2004 (Fig. 6) are used for the calculation.

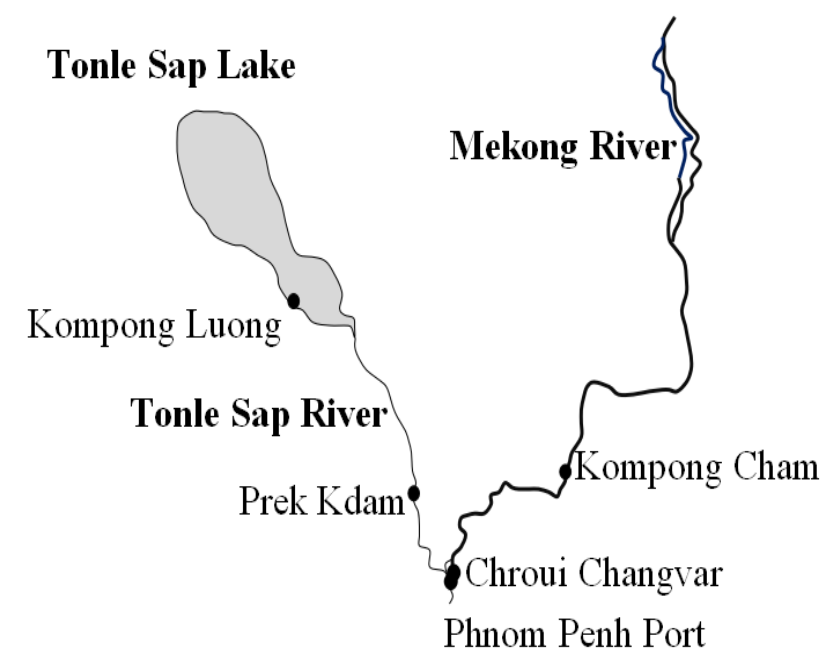

Figure 6. Locations of the sections in river-lake interaction system

In this study, BTOP Model was applied to generate the hydrological boundary conditions of TSL area. The implementation of the model in Mekong River basin needed topographic, land cover, soil type, NDVI and meteorological data sets.

The USGS-GTOPO30 was used in this paper to extract topographic information such as channel network, sub-basin division, basin boundary, flow accumulation and direction, and channel slope and length. Land cover data used the International Geosphere Biosphere Program (IGBP) Version 2 with 30 min resolution and 17 types of land cover. The data was converted into $8-\mathrm{km}$ resolution by assigning the biggest potion of the type in each $8 \times 8$ cell. The soil map of the Food and Agriculture Organization (FAO) was used to describe the soil type. A total 23 soil textural classes in the MR basin and different percentage contents of three types of soil were considered: sand, silt and clay. With respect to NDVI data, average 10-day and monthly NDVI data from NOAA-AVHRR NDVI data set were used in this study. Spatial variation in precipitation was considered based on the Thiessen polygon method, and data from 65 gauging stations were used. Observed precipitation gauging data were obtained from the Mekong River Commission. Other meteorological input data sets including monthly mean temperature, diurnal temperature range, cloud cover and actual vapor pressure, mean monthly wind speed were provided by the Climate Research Unit (CRU), University of East Anglia in UK.

\section{YHyM application in Tonle Sap}

The river network system in Tonle Sap Lake catchment was generated from DEM data as shown in Figure 7. Ten points at which river network intersected the balance system boundary were acquired. Then, all the hydrological information in each block of 
the intersections were output using YHyM, which included runoff, precipitation $(\mathrm{P})$, potential evaporation $\left(E_{p}\right)$ and actual evaporation $\left(E_{a}\right)$. These output data were used as input for the simulation of water balance.

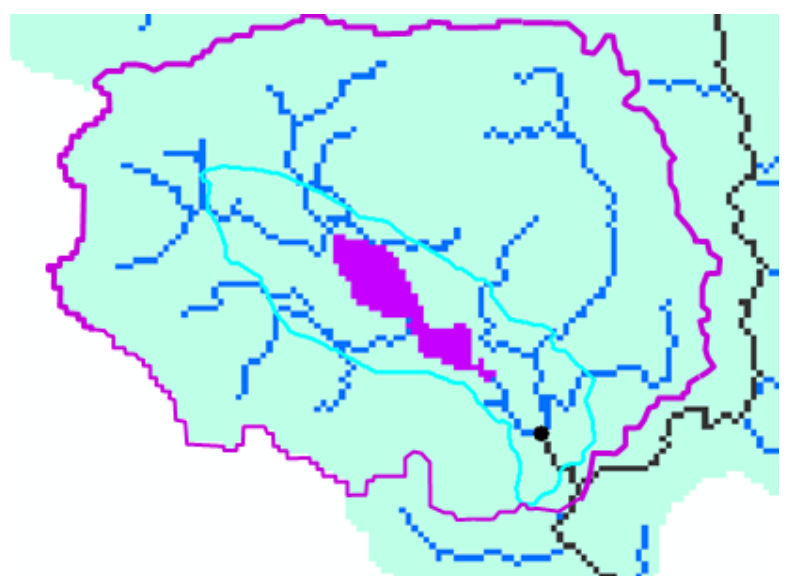

Figure 7. River net in TSL catchment

The sum of the runoff generated in these ten blocks was considered as the water flows into TSL contributed from tributaries, which varied from less than $100 \mathrm{~m}^{3} / \mathrm{s}$ to more than $15,000 \mathrm{~m}^{3} / \mathrm{s}$ in the period of 1987-2000, with an average discharge of $570 \mathrm{~m}^{3} / \mathrm{s}$. The average values of precipitation, potential evaporation and actual evaporation considered in the ten intersection grids provided by YHyM were used in the balance system of RLWE.

Daily observed water level data sets in Kompong Luong in 1980-2002 are used to analyze flood frequency in this region. Based on derived flood frequency curve of Kompong Luong, year 2000 and 1998 were selected as typical 1-20 wet year and typical 1-20 dry respectively.

\section{Model calibration and validation}

Based on the previous validation performance of YHyM and RLWE models, all the items in the balance system of RLWE were considered to be accurate, except the water consumption. Trial-and-error method was used to optimize parameter $\alpha$ by minimizing the difference between water volume of TSL calculated using the balanced equation and estimate, by converting observed water elevation Hkl (gauged stage at Kompong Luong) into water volume, based on the relationship between water level and lake water volume illustrated in the previous chapter.

The value of $\alpha$ obtained from optimization based on the data of 1987-1995 was 0.0051. For validation of the coupled model, the calibrated value of $\alpha$ was applied to estimate the daily water volume of TSL for the period of 1996-2000. The average daily absolute error in the period of 1996-2000 was $4 \times 10^{10} \mathrm{~m}^{3}$ (average $V_{\text {obs: }}: 21 \times 10^{10} \mathrm{~m}^{3}$ ), and comparison between observation and simulation is shown in Figure 8 . The temporal variation of water volume was well reproduced by the simulation. According to the figure, the calculated $\mathrm{V}$ was underestimated, especially at the peak time. It probably results from the fact that the constant $\alpha$ cannot reflect the temporal variation of water consumption. Moreover, the assumption that water consumption was totally dominated by water volume at the specific day was another limitation. 


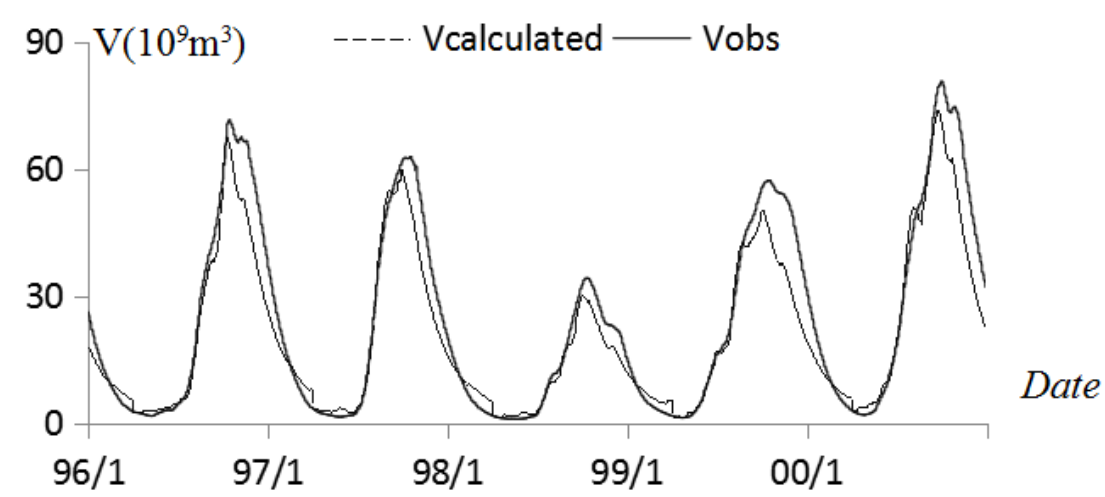

Figure 8. Validation of daily water consumption

\section{GCMs}

\section{Methodology}

Generally, future changes in climate are informed by the global climate models (GCM). In this study, 23 GCMs from IPCC were used for assessment of MR basin. Rainfall output of $23 \mathrm{GCMs}$ and 65 gauge data from 1987 to 2000 were compared to check the performance of each GCM in upper, middle and lower MR basin. The details are shown in Figure 9.

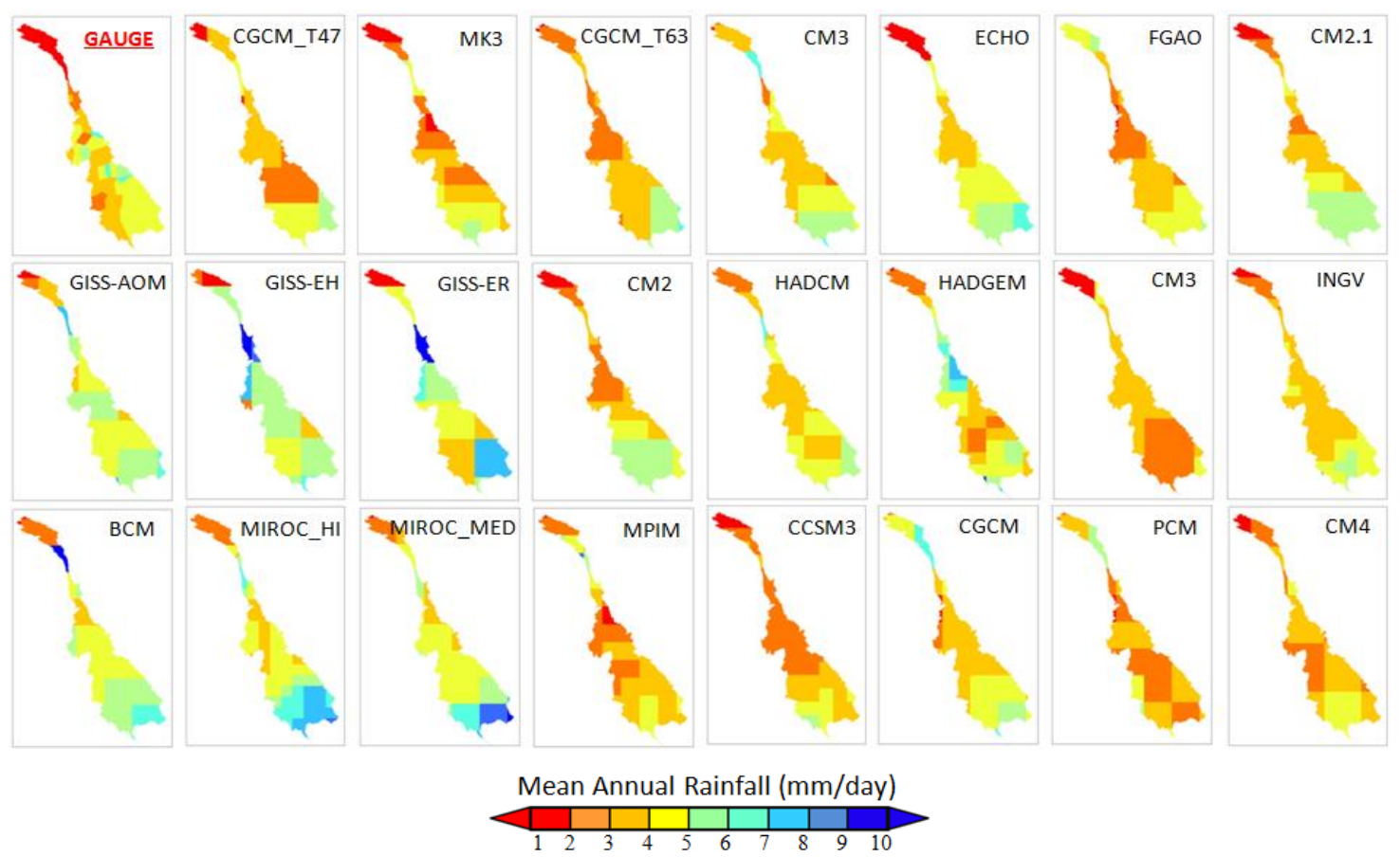

Figure 9. Rainfall output of 23 GCMs and gauge data from 1987 to 2000

Four indices were applied to describe the performance of each GCM:

1. Nash-Sutcliffe efficiency (NSE):

This is normalized statistic that determines the relative magnitude of the residual variance, compared to the observed data variance (Moriasi et al., 2006) in Equation 8: 


$$
N S E=1-\left[\frac{\sum_{i=1}^{n}\left(Y_{i}^{o b s}-Y_{i}^{\text {sim }}\right)^{2}}{\sum_{i=1}^{n}\left(Y_{i}^{0 b s}-Y_{i}^{m e a n}\right)^{2}}\right]
$$

2. Correlation coefficient:

This describes the degree of collinearity between simulated and observed data.

3. Coefficient of variation $(\mathrm{CV})$ :

This is a normalized measure of dispersion of a probability distribution.

4. Skill scores/M-statistic:

These represent the goodness of fit at simulating rainfall (Perkins et al., 2007).

$$
\mathrm{S}_{\text {score }}=\sum_{1}^{n} \min \text { imum }\left(Z_{M}, Z_{O}\right)
$$

where $n$ is the number of bins in Equation 9, $Z m$ is the frequency of values in a given bin from GCM, and $Z o$ is the frequency of values in a given bin from the observed data.

First, outputs of the 23 GCMS from IPCC (AR4, 1987-2000) were used to calculate the area average rainfall for upper, middle and lower parts of MR basin. Then, values of the 4 indices were calculated for each model in each part of the MR basin, relative to the gauge data in the same time period. Then, ranking was made, based on the values of each index in every part: $R_{i}^{n}$, where $i$ is the index, $n$ is the part of the MR basin. All ranks of each model were summed up in Equations 10:

$$
S_{m}=\sum_{\substack{i=1-4 \\ n=1-3}} R_{i}^{n}
$$

where $S m$ is the score of each GCM. Based on the scores in upper, middle and lower part in MR basin, the top five models were applied to derive an ensemble data. The information for these five GCMs are list in Table 1.

Table 1. Information of the top five GCMs

\begin{tabular}{c|c|c}
\hline Model & Center & Horizontal resolution \\
\hline NIES: MIROC3_2-HI & NIES, Japan & $1.12 \times 1.12$ \\
\hline CNRM: CM3 & INM, Russia & $5.0 \times 4.0$ \\
\hline CONS: ECHO-G & MIUB, Germany \\
& $\begin{array}{c}\text { METRI, Korea } \\
\text { M\&D, Germany }\end{array}$ & $3.8 \times 3.8$ \\
\hline CSIRO: MK3 & CSIRO, Australia & $1.9 \times 1.9$ \\
\hline UKMO: HADGEM1 & UKMO, UK & $1.9 \times 1.25$ \\
\hline
\end{tabular}

The potential impact of climate change on MR-TSL interaction system was analyzed using the coupled model. For the scenario analysis, future projected precipitation data were prepared using GCM output. In general, due to the difficulties in quantitative assessment of precipitation with GCM, "bias correction" was applied when GCM output was used for basin scale hydrological analysis.

As has been pointed out by Shibuo and Kanae (2010), proper bias correction method should be selected depending on the purpose of analysis. In this study, constant monthly scaling was used for bias correction. The modeled monthly changes (change ratio for each month) were applied to historical daily precipitation time series for producing future projected precipitation. This is one of the most widely used methods for assessing 
the impact of climate change on water resource, and is appropriate for long-term water balance analysis.

In this study, outputs from the 5 GCMs were obtained from IPCC AR4 for the 20th Century experiment $(20 \mathrm{c} 3 \mathrm{~m})$, and SRES SRA1B experiment was used for current and future precipitation. The A1 storyline and scenario family describe a future world of very rapid economic growth, global population that peaks in mid-century and the declines thereafter, and rapid introduction of new and more efficient technologies. For the A1B, balance was defined as not relying too heavily on one particular energy source, on the assumption that similar rates of improvement applied to all energy supplies and end-use technologies. In addition, modeled monthly changes were calculated using the data for 1981-2000 (for 20c3m) and 2046-2065, 2080-2099 (for SRA1B). The results of monthly ratios for upper, middle and lower parts in MR basin are shown in Figure 10.
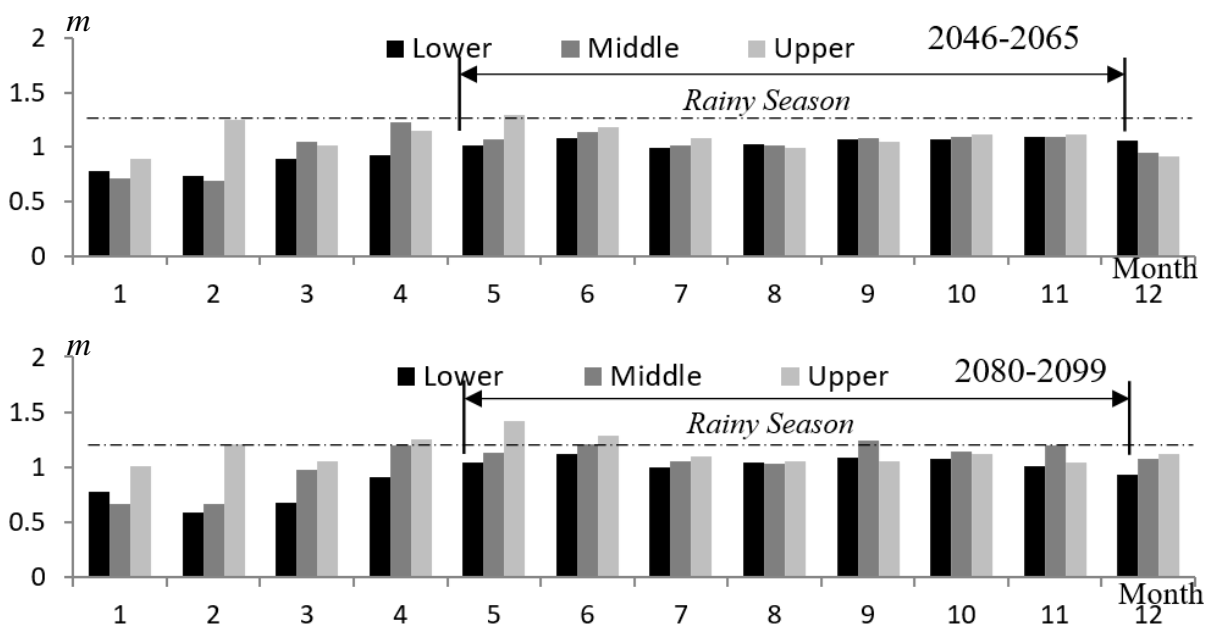

Figure 10. Monthly ratios in MR basin

\section{Results and discussion}

Typical wet year (20-year return period) and typical dry year (20-year return period) were chosen, based on the derived flood frequency curve of main MR. Through input, the future scenario precipitation in the YHyM and RLWE models, and daily water volume of TSL in a typical wet year and dry year were calculated. The results are shown in Figure 11.
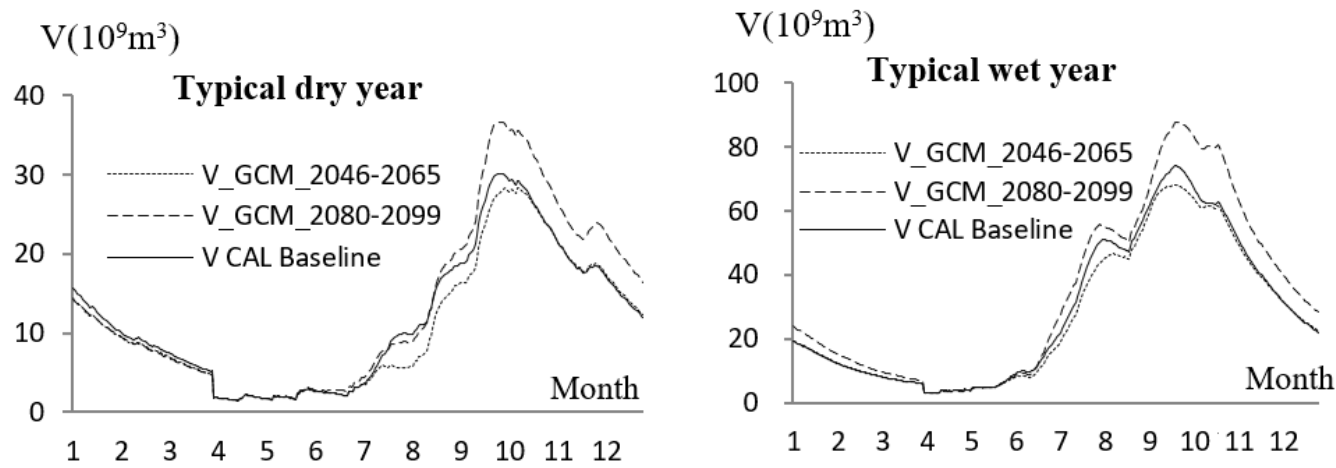

Figure 11. Daily water volume of TSL in typical years under future scenario 
In the later part of the rainy season (August-November), the total amount of precipitation changed more clearly than in other seasons, and runoff of main stream, tributary inflow, and water exchange between TSL and MR were also changed accordingly. These result in remarkable changes in water volume of TSL during this season. Values of the components in the water balance system in different typical years for the current period and future scenarios are listed in Table 2 Vtri $\left(10^{10} \mathrm{~m}^{3}\right)$ is the total water volume from tributaries within one year, $\operatorname{Vex}_{i n}\left(10^{10} \mathrm{~m}^{3}\right)$ is the water volume from MR flow into TSL within one year, Vex out $\left(10^{10} \mathrm{~m}^{3}\right)$ is the water volume from TSL flow into MR within one year, $\mathrm{W}\left(10^{10} \mathrm{~m}^{3}\right)$ is the total water consumption within one year, $\mathrm{P}$ E $\left(10^{10} \mathrm{~m}^{3}\right)$ is the total volume of precipitation minus evaporation within balanced system boundary in one year, and $\max \mathrm{V}\left(10^{10} \mathrm{~m}^{3}\right)$ is the maximum lake water volume calculated by coupling RLWE with YHyM.

Table 2. Water budgets in balanced system of TSL

\begin{tabular}{c|c|c|c|c|c|c}
\hline Year & Vtri & Vexin & Vexout & W & P-E & max V \\
\hline Wet (current) & 2.8 & 6.6 & 4.5 & 5.3 & 0.9 & 7.4 \\
Wet (46-65) & 2.8 & 5.8 & 3.8 & 5.0 & 0.8 & 6.8 \\
Wet (80-99) & 3.2 & 8.2 & 5.2 & 6.3 & 0.5 & 8.7 \\
\hline Dry (current) & 1.1 & 2.5 & 1.9 & 2.2 & 0.5 & 3.0 \\
Dry (46-65) & 1.1 & 2.2 & 1.7 & 2.0 & 0.4 & 2.8 \\
Dry (80-99) & 1.3 & 3.1 & 2.0 & 2.5 & 0.5 & 3.6 \\
\hline
\end{tabular}

Based on comparisons, the maximum water volume of TSL will decrease in future in the period 2046-2065, and increase in the period 2080-2099. Water flow from the MR made the largest contribution to changes in maximum water volume of the TSL.

The predicted changes in the water income components (2046-2065) in TSL balanced system were as follows: $\max V$ will decrease by $0.6 \times 10^{10} \mathrm{~m}^{3}$ and $0.2 \times 10^{10} \mathrm{~m}^{3}$ in typical wet and dry years, respectively; P-E will decrease by $0.1 \times 10^{10} \mathrm{~m}^{3}$ in typical wet and dry year; Vtri will not change too much; Vexin decrease by $0.8 \times 10^{10} \mathrm{~m}^{3}$ and $0.3 \times 10^{10} \mathrm{~m}^{3}$ in wet and dry years, respectively. The predicted changes in water income components (2080-2099) in TSL balanced system were as follows: $\max \mathrm{V}$ will increase by $1.3 \times 10^{10} \mathrm{~m}^{3}$ and $0.6 \times 10^{10} \mathrm{~m}^{3}$ in typical wet and dry years, respectively, P-E will decrease by $0.4 \times 10^{10} \mathrm{~m}^{3}$ in typical wet year, but there will be no obvious change in typical dry year; Vtriwill increase by $0.4 \times 10^{10} \mathrm{~m}^{3}$ and $0.2 \times 10^{10} \mathrm{~m}^{3}$ in typical wet and dry year, respectively, while Vexin will increase by $1.6 \times 10^{10} \mathrm{~m}^{3}$ and $0.6 \times 10^{10} \mathrm{~m}^{3}$ in wet and dry years, respectively.

\section{Conclusion}

This study has successfully modeled the MR-TSL interaction system for water resource assessment and river basin management. The major contribution of this study is the development of an integrated River Lake Water Exchange (RLWE) model coupled with YHyM (a grid-based distributed hydrological model) in Tonle Sap Lake area. Using the coupled model, discharge contributions to TSL from tributaries, daily lake water volume, water exchange between the MR and TSL, and daily consumptive water use in TSL area were analyzed and discussed. In addition, the potential impact of 
climate change on TSL hydrological system were determined through the application of the coupled model.

The potential impact of climate change on MR-TSL interaction system was analyzed using the coupled model. The modeled monthly changes were applied to historical daily precipitation time series for producing future projected precipitation, and constant monthly scaling was used for bias correction. GCM output was obtained from IPCC AR4. The current and future scenarios in this study represent the periods 1981-2000 and 2046-2065, 2080-2099, respectively. Under future scenario, peak water volume will decrease in 2046-2065 and increase in 2080-2099 in typical dry and wet years. Water flow from the MR river the largest contribution to the reduction of maximum water volume of TSL.

The results from different future scenarios showed the potential impact on MR-TSL interaction system. The maximum water volume of TSL will decrease, while minimum water volume will increase under future climate change situations (2046-2065). Moreover, the maximum water volume of TSL will increase under future climate change situations (2080-2099). The range of variation in lake area will decrease as a result of these changes. These scenarios indicate that dams on lake tributaries will not have much effect on TSL, which implies that exchange water is the dominant item within the interaction system.

This study analyzed the hydrological response to future climate change, but does not consider water quality issue. Due to the economic development, water quality management will become a key point of water resource management in the near future. The water quality response study under global climate change can be a future research.

Acknowledgments. This work was financially supported by the Innovation capacity building project of Jiangsu provincial Department of science and technology (BM2018028 ), MEXT and G-COE Program of University of Yamanashi, Japan. Hydrological data for Tonle Sap Lake was provided by International Centre for Water Hazard and Risk Management (ICHARM) under the project of Research Revolution 2002 (RR2002). We also acknowledge the modeling groups, the Program for Climate Model Diagnosis and Inter-comparison (PCMDI) and the WCRP's Working Group on Coupled Modeling (WGCM) for their roles in making available the WCRP CMIP3 multi-model dataset.

\section{REFERENCES}

[1] Ao, T. (2001): Development of a distributed hydrological model for large river basins and its application to Southeast Asian rivers. - PhD Thesis, University of Yamanashi, Kofu, Japan, pp. 1-124.

[2] Ao, T., Ishidaira, H., Takeuchi, K., Kiem, A., Yoshitani, J., Fukami, K., Magome, J. (2006): Relating BTOPMC model parameters to physical features of MOPEX basins. Journal of Hydrology 320(1-2): 84-102.

[3] Ao, T., Takeuchi, K., Ishidaira, H., Fukami, K., Kaneki, M. (1999): The Naka River floods analyses by BTOPMC method. - Proceedings of International Symposium on Floods and Droughts, Nanjing China, 18-21 October 1999, pp. 414-420.

[4] Ao, T., Takeuchi, K., Ishidaira, H. (2000): A distributed rainfall-runoff model for a large catchment - a preliminary application to the Mekong basin. - Proceedings of the AP FRIEND Workshop on Mekong Basin Study 19: 93-102.

[5] Ao, T., Yoshitani, J., Takeuchi, K., Fukami, K., Mutsuura, T., Ishidaira, H. (2003a): Effects of sub-basin scale on runoff simulation in distributed hydrological model: 
BTOPMC. - Weather Radar Information and Distributed Hydrological Modeling 282: 227-234.

[6] Ao, T., Takeuchi, T., Ishidaira, H., Yoshitani, J., Fukami, K., Matsuura, T. (2003b): Development and application of a new algorithm for automated pits removal for grid DEMs. - Hydrological Sciences Journal 48(6): 985-997.

[7] Campbell, I. C. (2016): Integrated management in the Mekong River Basin. Ecohydrology \& Hydrobiology 16(4): 255-262.

[8] Chan, S., Putrea, S., Sean, K., Hortle, K. G. (2003): Using local knowledge to inventory deep pools, important fish habitats in Cambodia. - Proceedings of the 6th Technical Symposium on Mekong Fisheries, Pakse, Lao PDR 26-28 November 2003, pp. 34: 65.

[9] Ishidaira, H., Takeuchi, K., Ao, T. (2000): Hydrological simulation of large river basins in Southeast Asia. Proceedings Fresh Perspectives on Hydrology and Water Resources in Southeast Asia and the Pacific, Christ Church. - Technical Document in Hydrology 7: 53-54.

[10] Keskinen, M. (2006): The lake with floating villages: socio-economic analysis of the Tonle Sap Lake. - International Journal of Water Resources Development 22: 463-480.

[11] Kiem, A. S., Hapuarachchi, H. P., Takeuchi, K. (2004a): Impacts of climate variability on streamflow in the Mekong River: an interesting challenge for hydrological modeling. Proceedings of 7th International River Symposium 31: 4.

[12] Kiem, A. S., Hapuarachchi, H. P., Ishidaira, H., Magome, J., Takeuchi, K. (2004b): Uncertainty in hydrological predictions due to inadequate representation of climate variability impacts. - Proceedings of AOGS 1st Annual Meeting \& APHW 2nd Conference 12: 5-9.

[13] Kiem, A. S., Geogievsky, M. V., Hapuarachchi, H. P., Ishidaira, H., Takeuchi, K. (2005): Relationship between ENSO and snow-covered area in the Mekong and Yellow River basins. - IAHS Publication 296: 255-264.

[14] Kummu, M., Nikula, J. (2006): Ecosystem management of Tonle Sap Lake: An integrated modelling approach. - International Journal of Water Resources Development 22: 497-519.

[15] Kummu, M., Sarkkula, K. (2008): Impact of the Mekong River Flow Alteration on the Tonle Sap Flood Pulse. - AMBIO A Journal of the Human Environment 37(3): 185-192.

[16] Kummu, M., Penny, D., Sarkkula, J., Koponen, J. (2008): Sediment - curse or blessing for Tonle Sap Lake? - AMBIO A Journal of the Human Environment 37(3): 158-163.

[17] Moriasi, D. N., Arnold, J. G., Van Liew, M. W., Binger, R. L., Harmel, R. D., Veith, T. (2006): Model evaluation guidelines for systematic quantification of accuracy in watershed simulations. - Transactions of the ASABE 50(3): 885.

[18] Ogston, A. S., Allison, M. A., Mullarney, J. C., Nittrouer, C. A. (2017): Sediment- and hydro-dynamics of the Mekong Delta: from tidal river to continental shelf. - Continental Shelf Research 147: 1-6.

[19] Perkins, S. E., Pitman, A. J., Holbrook, N. J. (2007): Evaluation of the AR4 climate models' simulated daily maximum temperature, minimum temperature, and precipitation over Australia using probability density functions. - Journal of Climate 20: 4356-4376.

[20] Shibuo, K., Kanae, S. (2010): Comparisons of bias correction methods for climate model's daily precipitation - from a heavy rainfall perspective. - Annual Journal of Hydraulic Engineering 54: 235-240.

[21] Sutherland, J. W., Norton, S. A., Short, J. W., Navitsky, C. (2018): Modeling salinization and recovery of road salt-impacted lakes in temperate regions based on long-term monitoring of Lake George, New York (USA) and its drainage basin. - Science of the Total Environment 637: 282-294.

[22] Sverdrup, J. S. (2002): Fisheries in the Lower Mekong Basin: Status and Perspectives. MRC Technical Paper No. 6. Mekong River Commission, Phnom Penh, Cambodia.

[23] Szesztay, K. (1974): Water balance and water level fluctuations of lakes. - Hydrological Sciences-Bulletin-des Sciences Hydrologiques 1974: 73-84. 
[24] Takeuchi, K., Ao, T., Ishidaira, H. (1999): Introduction of block-wise use of TOPMODEL and Muskingum-Cunge method for the hydroenvironmental simulation of a large ungauged basin. - Hydrological Sciences Journal (Journal Des Sciences Hydrologiques) 44(4): 633-646.

[25] TERRA (2007): MRC silent as mainstream dams move forward. - TERRA Press Briefing, 8 November 2007, Bangkok.

[26] Trisurat, Y., Aekakkararungroj, A., Ma, H. (2018): Basin-wide impacts of climate change on ecosystem services in the Lower Mekong Basin. - Ecological Research 33: 73-86.

[27] Wu, S., Ishidaira, H., Sun, W. (2010): Potential impact of Sambor Dam project on interaction between Mekong River and Tonle Sap Lake. - Annual Journal of Hydraulic Engineering 54: 109-114.

[28] Zhou, M., Ishidaira, H., Hapuarachchi, H. P., Georgievsky, M., Takeuchi, K. (2005): Roles of snow, infiltration and saturation excess processes in runoff generation of Yellow River basin. - Symposium on Methodology in Hydrology 135: 196.

[29] Zhou, M., Ishidaira, H., Hapuarachchi, H. P., Magome, J., Kiem, A. S., Takeuchi, K. (2006a): Estimating potential evapotranspiration using Shuttleworth-Wallace model and NOAA-AVHRR NDVI data to feed a distributed hydrological model over the Mekong River basin. - Journal of Hydrology 327(1-2): 151-173.

[30] Zhou, M., Ishidaira, H., Hapuarachchi, H. P., Magome, J., Takeuchi, K. (2006b): Adaptive Muskingum-Cunge routing method for distributed hydrological modeling in large river basins. - 3rd APHW Conference 10: 16-18. 